\title{
PROMOTION OF ENGLISH IN TERTIARY EDUCATION OF KAZAKHSTAN
}

\author{
Damira Akynova $^{1 \star}$, Atirkul Agmanova ${ }^{2}$, Zhanargul Beisembayeva ${ }^{3}$ \\ ${ }^{1}$ Dr, L.N.Gumilyov Eurasian National University, KAZAKHSTAN, akynova.d@yandex.kz \\ ${ }^{2}$ Prof. Dr., Pavlodar Pedagogical University, KAZAKHSTAN, agmanova@mail.ru \\ ${ }^{3}$ Dr, L.N.Gumilyov Eurasian National University, KAZAKHSTAN, zhannabei@mail.ru \\ ${ }^{*}$ Corresponding Author
}

\begin{abstract}
Globalization and integration processes, which are taking place in Kazakhstan, have led to the dynamic development of English. Due to the general trends in the world, there have been significant changes in the educational area of Kazakhstan. The study aims at determining the attitudes towards promoting English through education. To achieve it, interviews with teachers and students, as well as surveys of teachers and students have been used. The results demonstrate that English contributes to promotion of Kazakhstan's education and science, provides access to the research literature, and determines the competitiveness of future specialists in the international market.
\end{abstract}

Keywords: English, Kazakhstan, higher education, attitude.

\section{INTRODUCTION}

Currently, English is considered as a means to social, economic, educational and cultural development of society. Promotion of English is supported by the majority of states on the political level which reflects its importance in the international community. One of the key areas in promoting English is the educational area; therefore, in the context of globalisation and the imperative of time, the issues of English functioning in education are among the most topical ones.

The purpose of the paper is to determine the reasons for promoting English through the system of higher education. To achieve this purpose, the following questions have been posed:

-What is the policy towards English in higher education?

-Why is English promoted through education?

This study was conducted using quantitative methods, such as critical interviews with teachers, and students the university administration, as well as surveys of teachers and students.

The paper is structured as follows: an analysis of studies on the promotion of English in higher education through a theoretical background. Then, the current state of higher education of the Republic of Kazakhstan and the role of English in the linguistic space of Kazakhstan are analysed. The description of the research methodology includes the procedure for conducting the questionnaires and interviews, as well as the description of respondents. The obtained data are analysed in the results.

\section{HIGHER EDUCATION IN KAZAKHSTAN}

Due to global integration, expansion of information space and rapid development of innovative technologies in the world, the educational system of the Republic of Kazakhstan is undergoing significant changes. 
In the Address "Socio-economic modernisation - the main vector of development of Kazakhstan", dated January 27, 2012, President of the Republic of Kazakhstan Nursultan Nazarbayev emphasises the qualitative growth of human capital in Kazakhstan, which means, first of all, the modernisation of the educational system. The President underlined the fact that "the main advantage of our country is multiethnicity and multilingualism" and "one of the key factors of success of the modernisation process is updating the national educational system" (Address of the President: 2011).

One of the main goals within the framework of the Kazakhstan government's policy is to become one of the 30 most competitive countries (Address of the President: 2012).

Significant socio-economic reforms have been conducted over the past decade which gave a new impetus for the transformation of the educational system. Legal and regulatory frameworks in the field of education have been updated and improved, the scope of international cooperation has been expanded and all levels of education have been modified.

The aforementioned changes have mainly influenced the higher educational system. Integration and internationalisation of the Kazakhstani educational system, university autonomy, international academic mobility, independent accreditation of higher educational institutions, systemic synthesis of science, education and innovation, lifelong learning, etc. are the main objectives at the present stage of development of higher education of the Republic of Kazakhstan.

With the adoption of the State Program of Education Development in the Republic of Kazakhstan for 20052010, the sphere of higher education entered a new stage of development and functioning (State Program: 2004). In 2007, Kazakhstan's high schools adopted a three-stage system of education: bachelor - master $\mathrm{PhD}$, the legal bases of which are reflected in the Law of the Republic of Kazakhstan "On Education". And in 2009, Classifier of higher and postgraduate education was introduced, which corresponds to the basic provisions of the Bologna Declaration and is directed to a system of international classification of education. One of the objectives of its representation in the educational space of Kazakhstan is to ensure transparency, comparability and recognition of diplomas and qualifications at an international level. One of the first steps to achieve the goal of higher education - an entry into the European Higher Education Area, in the global educational environment as a whole - has been the signing of the Bologna Declaration by the Republic of Kazakhstan at the 2010 II Bologna Forum of Ministers of Education of the Bologna process statesparticipants. During the implementation of the fundamental principles of the Bologna Declaration, 60 higher educational institutions of the Republic of Kazakhstan entered the Great Charter of Universities (National report: 2011).

Thus, the Republic of Kazakhstan is trying to improve the quality of education and to raise the competitiveness of future professionals in the global market. As stated above, in the context of globalisation, English gets the status of the global, international language, which serves as a lingua franca in the world. Issues on the status of English in the higher educational system of the Republic of Kazakhstan are presented in the next section.

\section{METHODOLOGY}

The research was conducted using higher educational institutions in the city of Astana. For the most part, it was held at L.N. Gumilyov Eurasian National University. To conduct the study, two questionnaires were developed: for students and teachers, respectively. The structure of the questionnaire was as follows:

Block A - Information about participants.

Block B - Attitudes toward promotion of English.

Each question had several answers using a 5-point Likert scale which is differentiated from 1 - Strongly agree, 2 - Agree, 3 - Disagree, 4 - Strongly disagree and 5 - Not given. The data were analysed with SPSS 16 programme.

467 students from 1 to 4 courses, learning English as a second language, and 53 English language teachers participated in the questionnaire. 21 students and 12 teachers participated in the interviews.

$65 \%$ of the students were female, $35 \%$ were male. $96.5 \%$ of the teachers were female, and only $3.5 \%$ were males. The dominance of females is due to the fact that the majority of students and teachers in the Department of Foreign Languages are females. Coverage of respondents-students on the year of study was evenly distributed: $27 \%$ of students were freshmen, $22 \%$ were sophomores, $25 \%$ were junior students and $26 \%$ were senior students. The native language for $61.5 \%$ of students was Kazakh, $34.2 \%$ of them indicated Russian, and $4.3 \%$ indicated Uzbek as their mother tongue. $53.2 \%$ of the teachers indicated Kazakh as their 
mother tongue and for $46.8 \%$ of the participants it was Russian. Distribution of respondents-students according to their proficiency in English is presented as follows.

Most of the students assessed themselves as Intermediate users (47\%) and Upper-Intermediate users (31\%). $12 \%$ of students referred to themselves as Beginner level of English. $12 \%$ of respondents assessed themselves as Pre-Intermediate English language users, and only 1\% of respondents believe that they spoke fluent English.

English language proficiency of teachers based on their assessment is given as follows. The vast majority of teachers (86\%) considered themselves as Upper-Intermediate users of English, and $14 \%$ referred themselves to the Advanced level.

\section{RESULTS AND DISCUSSION}

Survey data of students on the promotion of English in Kazakhstan are presented in Table 1.

Table 1. The attitude of students on promotion of English in the educational space of Kazakhstan

\begin{tabular}{|c|c|c|c|c|c|c|}
\hline № & Possible answers & $\begin{array}{l}\text { Strongly } \\
\text { agree (\%) }\end{array}$ & $\begin{array}{l}\text { Agree } \\
(\%)\end{array}$ & $\begin{array}{l}\text { Disagree } \\
(\%)\end{array}$ & $\begin{array}{l}\text { Strongly } \\
\text { disagree } \\
\text { (\%) }\end{array}$ & $\begin{array}{l}\text { Not given } \\
\text { (\%) }\end{array}$ \\
\hline 1 & $\begin{array}{l}\text { I approve the policy of } \\
\text { promotion of English } \\
\text { through education. }\end{array}$ & 3,2 & 67 & 24,3 & 0 & 5,5 \\
\hline 2 & $\begin{array}{l}\text { Learning English } \\
\text { promotes } \\
\text { competitiveness of a } \\
\text { university graduate in } \\
\text { the labour market. }\end{array}$ & 26,7 & 54,8 & 4,5 & 1,3 & 12,7 \\
\hline 3 & $\begin{array}{l}\text { Promotion of English at } \\
\text { a university allows } \\
\text { joining the global } \\
\text { academic community. }\end{array}$ & 13,4 & 63,3 & 5,5 & 0 & 17,8 \\
\hline 4 & $\begin{array}{l}\text { English gives access to } \\
\text { the world's research } \\
\text { literature. }\end{array}$ & 34,7 & 51,1 & 6,4 & 2,1 & 5,7 \\
\hline 5 & $\begin{array}{lr}\text { The language of } \\
\text { instruction in the } \\
\text { universities should be } \\
\text { English } & \text { for } \\
\text { competitiveness } & \text { of } \\
\text { higher education. } & \end{array}$ & 2,3 & 24,1 & 45 & 3,1 & 25,5 \\
\hline 6 & $\begin{array}{l}\text { I approve of the policy of } \\
\text { training polilingual } \\
\text { specialists. }\end{array}$ & 9,3 & 72,4 & 3 & 0 & 15,3 \\
\hline 7 & $\begin{array}{l}\text { Development of three } \\
\text { languages in higher } \\
\text { education will } \\
\text { strengthen the position } \\
\text { of English. }\end{array}$ & 31,9 & 57,3 & 4,2 & 0,5 & 6,1 \\
\hline 8 & Promotion of English in & 13 & 34,6 & 35,2 & 13,9 & 3,3 \\
\hline
\end{tabular}




\begin{tabular}{|c|c|c|c|c|c|c|}
\hline & $\begin{array}{l}\text { higher education has a } \\
\text { negative effect on the } \\
\text { development and } \\
\text { promotion of Kazakh. }\end{array}$ & & & & & \\
\hline 9 & $\begin{array}{l}\text { Promotion of English in } \\
\text { higher education has a } \\
\text { negative effect on the } \\
\text { development of the } \\
\text { Kazakh national identity. }\end{array}$ & 14 & 34,6 & 35,2 & 12,9 & 3,3 \\
\hline 10 & $\begin{array}{l}\text { Promotion of English is } \\
\text { a threat to the future of } \\
\text { the Kazakh language } \\
\text { and culture. }\end{array}$ & 0 & 6,2 & 87,4 & 5,7 & 0,7 \\
\hline
\end{tabular}

Table 1 demonstrates that the majority of respondents (70.2\%) favour the policy of promoting English through education while $24.3 \%$ did not approve of this policy and $5.5 \%$ of respondents did not answer it. $81.5 \%$ of respondents believe that learning English contributes to the competitiveness of university graduates in the labour market while only a small number of participants $(5.8 \%)$ disagreed with the statement and $12.7 \%$ of respondents could not give an answer to this statement. $76.7 \%$ of students believe that the promotion of English in higher education allows it to join the international academic community with $5.5 \%$ of respondents not agreeing with it and $17.8 \%$ of the participants not answering the question. The vast majority of respondents (85.8\%) believe that English provides access to the world's research literature while $8.5 \%$ did not agree with this statement and $5.7 \%$ did not answer it. The answers to the statement 'The language of instruction in the universities should be English for competitiveness of higher education' are as follows: a relatively small number of respondents $(26.4 \%)$ agree with it, about half of the participants $(48.1 \%)$ disagree with it, and $25.5 \%$ did not answer it. $81.7 \%$ favour a policy of training polilingual staff, $3 \%$ did not approve, and $15.3 \%$ did not answer it. The vast majority of respondents (89.2\%) believe that the development of three languages in higher education will strengthen the position of English in the future, only $4.7 \%$ of respondents disagree with this statement, and $6.1 \%$ did not answer it. The answers to the statement 'Promotion of English in higher education has a negative effect on the development and promotion of Kazakh' are as follows: $47.6 \%$ of participants agree with it and approximately the same number of respondents $(49.1 \%)$ disagree with it. $3.3 \%$ of respondents found it difficult to answer this question. $47 \%$ believe that the promotion of English in higher education has a negative effect on the development of the Kazakh national identity with $49.7 \%$ disagreeing with this statement. A small number of respondents $(6.2 \%)$ agree that the promotion of English was a threat to the future of Kazakh and culture while the vast majority of respondents (93.1\%) disagree with this statement. The results show that, in general, the attitudes of students towards promotion of English are positive. English is regarded as a lingua franca, a necessary element in the system of higher education of the Republic of Kazakhstan.

Survey data of teachers on the promotion of English in Kazakhstan are presented in Table 2.

Table 2. The attitude of teachers on promotion of English in the educational space of Kazakhstan

\begin{tabular}{|l|l|l|l|l|l|l|}
\hline № & Possible answers & $\begin{array}{l}\text { Strongly } \\
\text { agree (\%) }\end{array}$ & Agree (\%) & $\begin{array}{l}\text { Disagree } \\
\text { (\%) }\end{array}$ & $\begin{array}{l}\text { Strongly } \\
\text { disagree } \\
(\%)\end{array}$ & $\begin{array}{l}\text { Not given } \\
\text { (\%) }\end{array}$ \\
\hline 1 & $\begin{array}{l}\text { I approve the policy of } \\
\text { promotion of English through } \\
\text { education. }\end{array}$ & 2 & 71 & 20,8 & 1,2 & 5 \\
\hline 2 & $\begin{array}{l}\text { Learning English promotes } \\
\text { competitiveness of a } \\
\text { university graduate in the } \\
\text { labour market. }\end{array}$ & 65,8 & 4,6 & 1,2 & 13,1 \\
\hline 3 & $\begin{array}{l}\text { Promotion of English at a } \\
\text { Prom }\end{array}$ & 63,3 & 5,5 & 7,1 & 8,6 \\
\hline
\end{tabular}




\begin{tabular}{|c|c|c|c|c|c|c|}
\hline & $\begin{array}{l}\text { university allows joining the } \\
\text { global academic community. }\end{array}$ & & & & & \\
\hline 4 & $\begin{array}{l}\text { English gives access to the } \\
\text { world's research literature. }\end{array}$ & 25,7 & 51,1 & 15,5 & 2,1 & 5,7 \\
\hline 5 & $\begin{array}{l}\text { The language of instruction } \\
\text { in the universities should be } \\
\text { English for competitiveness } \\
\text { of higher education. }\end{array}$ & 2,3 & 21,1 & 48,2 & 3,1 & 25,3 \\
\hline 6 & $\begin{array}{l}\text { I approve of the policy of } \\
\text { training } \\
\text { specialists. }\end{array}$ & 12,3 & 69,1 & 3,2 & 3,1 & 12,2 \\
\hline 7 & $\begin{array}{l}\text { Development of three } \\
\text { languages in higher } \\
\text { education will strengthen the } \\
\text { position of English. }\end{array}$ & 31,9 & 57,3 & 4,2 & 0,5 & 6,1 \\
\hline 8 & $\begin{array}{l}\text { Promotion of English in } \\
\text { higher education has a } \\
\text { negative effect on the } \\
\text { development and promotion } \\
\text { of Kazakh. }\end{array}$ & 11,2 & 35,2 & 34,5 & 14 & 5,1 \\
\hline 9 & $\begin{array}{l}\text { Promotion of English in } \\
\text { higher education has a } \\
\text { negative effect on the } \\
\text { development of the Kazakh } \\
\text { national identity. }\end{array}$ & 14,2 & 34,4 & 33,4 & 12,9 & $3,35,1$ \\
\hline 10 & $\begin{array}{l}\text { Promotion of English is a } \\
\text { threat to the future of the } \\
\text { Kazakh language and } \\
\text { culture. }\end{array}$ & 5,3 & 6,2 & 76,1 & 5,7 & 6,7 \\
\hline
\end{tabular}

As shown in Table 2, the majority of respondents (73\%) approve of the policy of promoting English through education while $22 \%$ did not favour this policy, and $5 \%$ of respondents did not answer it. $81.1 \%$ of respondents believe that learning English helps the competitiveness of university graduates in the labour market, only a small number of participants $(12.6 \%)$ disagree with the statement and $8.6 \%$ of respondents did not give an answer to this statement. $78.8 \%$ of respondents believe that the promotion of English in higher education allows it to join the international academic community. $5.5 \%$ of respondents did not agree with it while $17.8 \%$ of the participants did not answer the question. The majority of respondents $(76.8 \%)$ believe that English provides access to the world's research literature, $17.6 \%$ did not agree with this statement and $5.7 \%$ did not answer it. The answers of respondents to the statement 'The language of instruction in the universities should be English for competitiveness of higher education' are as follows: a relatively small number of respondents $(23.4 \%)$ agree with it, a little more than half of the participants (51.3\%) disagree with it, and $25.3 \%$ did not answer it. $81.4 \%$ favour a policy of training polilingual staff, $6.3 \%$ did not approve of it, and $12.2 \%$ did not answer it. The vast majority of respondents (89.2\%) believe that the development of three languages in higher education will strengthen the position of English in the future, only $4.7 \%$ of respondents disagree with this statement, and $6.1 \%$ did not answer it. The answers to the statement 'Promotion of English in higher education has a negative effect on the development and promotion of Kazakh' are as follows: $46.4 \%$ of participants agree with it and approximately the same number of respondents (48.5\%) disagree with it. $5.1 \%$ of respondents found it difficult to answer this question. $48.6 \%$ believe that the promotion of English in higher education has a negative effect on the development of the Kazakh national identity with $46.3 \%$ disagreeing with this statement. A small number of respondents (11.5\%) agree that the promotion of English is a threat to the future of the Kazakh language and culture, while the vast majority of respondents $(81.8 \%)$ disagree with this statement. The results show that, in general, the attitudes of teachers towards promotion of English are positive. However, there is an apparent anxiety about the future of the Kazakh language and culture. English is considered as one of the languages of higher 
education of the Republic of Kazakhstan which will allow Kazakhstan's education to reach an international level.

Interviews with teachers and students have also been conducted to reveal their attitude towards promotion of English. Respondents had the opportunity to choose the language of their answer: they were asked to answer in Kazakh, Russian or English. The following questions were asked in the interview:

-What is the policy towards English in higher education?)

-Why is English promoted through education?

-What are the prospects of Kazakh (Russian / English)?

- How do you feel about the policy of promoting three languages? Does the promotion of English influence development of Kazakh? Is English a threat to the future of Kazakh / Russian?

Most interviewees hold positive attitudes toward promoting English through education. The main reasons for promoting English are listed as follows:

-World language, which provides access to knowledge

- Access to get new and fresh information

- Kazakhstan's integration into the world community

- Competitiveness of future specialists in the world

- Mobility of students, opportunities to study abroad

- Promotion of education and science of Kazakhstan

I think that English is being promoted everwhere - on the Internet, through politics, economics, culture, through new scientific discoveries, which are usually given "English names". The main mission of educational institutions - is to prepare knowledgeable, skilled professionals. In this context, English is a very good tool to get a fresh, new information. Due to this reason, English is being widely introduced in the process of education. There are other reasons for the introduction of English in education: such as the integration of Kazakhstan into the world community, prompted by globalization, upcoming tourist inflow to Kazakhstan in connection with EXPO, etc., where every citizen of Kazakhstan should know a foreign language. (Teacher, 34 years old, female)

The following response is of great interest, which emphasises the political nature of the issue.

Why is English promoted through education? Because education is a great tool of implementation, management and control of some "innovations" by the state. The introduction of English is beneficial for all participants in the educational process: the government, educational institutions, and consumers of educational services. (Student, 4-course, 21 years old, male)

Respondents also point to the importance of English as a world language, emphasising the role of developed countries and the importance of science and technology in the promotion of English.

Most highly qualified universities are located on English-speaking countries such as England, USA and others. That is why English is in demand... The countries such as England and USA set rules, paradigms and "fashion" for education quality. We, being a developing country, try to obey their rules, standards and follow their examples. That's why the role of English language is crucial in Kazakhstani education. (Student, 3-course, 21 years old, female).

Education is tightly connected with science and technology. Nowadays science and technology is being developed abroad, mostly in English-speaking countries. In order to develop our country we have to accept Western technologies and with technologies come along the language. (Student, 1-course, 17 years old, male)

The respondents' answers regarding the prospects of the development of Kazakh, Russian and English, and the influence of English on the development of Kazakh and Russian are contradictory. Many of them believe that, in the future, Kazakh will have a stronger position than at present. However, some of them believe that there is a danger of extinction of Kazakh due to the expansion of English in the future. According to respondents, Russian will remain the language of international communication.

Opinions on the negative impact of English on Kazakh and Russian are unfounded. President Nursultan Nazarbayev put the objective of mastering three languages to all citizens of Kazakhstan in his Address 
(12.15.12) to the people. Nowadays even the knowledge of three languages is not enough. (Lecturer, 32 years old, female)

I believe that learning English does not influence our [Kazakh] language. Because despite the fact that we had been a part of Russia for many years, we have not forgotten our language. On the contrary, we have been developing it since independence. (Student, 19 years old, 3-course, male)

There are some concerns for the future of Kazakh: some of them believe that English is a threat to the development of Kazakh.

There is no doubt that there is a big threat of lowering the value of Kazakh. Not only for Kazakh, but also for all other languages. To date, about $50 \%$ of Kazakhstani citizens speak Kazakh (my opinion). With the growing influence of English the share of Kazakh language users will decline. It's sad for me, but it is inevitable. Trilingualism policy as a catalyst only increases the displacement Kazakh from everyday use. (Teacher, 44 years old, female)

According to Gumilyov, globalization leads to disappearance of traditions and history. Therefore Nazarbayev accepted the idea of Eurasianism, that is, if the world rolls on the route of globalization, we can not avoid the disappearance of Kazakh or its changes. English goes uphill, well, Russian, due to the fact that there are many Russian-speaking people, will hold on, so that is a possibility. As for Kazakh, even now, it is very weak compared with Russian. So, what is the probability that Kazakh will continue to evolve if it is pinned down by Russian and English? (Teacher, 51 years old, female)

Despite the pessimistic predictions of some respondents on the prospects of the development of Kazakh, most of them are optimistic believing that the position of the state language will be strengthened in the future. The majority of respondents believe that Russian will retain its position, as it is the language of international communication. A small part of the respondents believe that English can take the place of Russian in the linguistic space of Kazakhstan in the future. Almost all of the respondents believe that English will strengthen its position in higher education of the Republic of Kazakhstan.

\section{CONCLUSION}

Radical changes at all levels of the educational system of the Republic of Kazakhstan in recent years have determined the role of English to be an important component of the dynamic development of science and education. Entry into the world educational space, recognition of diplomas of Kazakhstan in the international arena are possible with the promotion of English in the educational system, therefore academic "lingua franca" of the world is regarded as one of the main mechanisms to promote Kazakhstan's education to the global level.

This article was an attempt to define the role and to study the peculiarities of English in higher education of Kazakhstan. In this study, the following objectives were addressed:

- The policy towards English in the field of higher education was determined;

- The main reasons for promoting English through the higher educational system were identified.

Based on the research, the following conclusions were made:

1) Attitudes towards promotion of English in higher education are characterised as positive and promising, which demonstrates the effectiveness of the policy of a trinity of languages. English is considered a language of successful integration into the global educational space, a powerful weapon in the competitive market, and the language of academic staff and students' exchange.

2) Survey data and interview data suggest that the prospects for the development of Kazakh, Russian and English have a positive tendency.

3) However, there are some concerns on the future of Kazakh. Informants suggest that it is necessary to develop Kazakh first. They believe that promotion of English may hinder the process of developing Kazakh.

Thus, the promotion of English in the new language policy is regarded as a deliberate step, which has received the support of the majority of the population, and, of course, raises the status of promoting higher education of the Republic of Kazakhstan onto the world stage.

This study is only the beginning stage; therefore, it shoud be developed by using both quantitative and qualitative methods as well as by differentiating the sample. The regional investigation is also needed in order to observe the general trends in functioning of English in Kazakhstan. 


\section{REFERENCE LIST}

Address of the President to the People of the Republic of Kazakhstan "New Kazakhstan in the new world" (2007), available from: http://www.kazak hemb.org.il/?CategorylD=250\&ArticlelD=551\&Page=1, accessed 9 October, 2012.

Address of the President to the People of the Republic of Kazakhstan "Social-economic modernization - the main vector of the development of Kazakhstan", available from:

http://www.akorda.kz/ru/page/poslanie-prezidenta-respubliki-kazakhstan-n-a-nazarbaeva-narodukazakhstana_1339760819, accessed 9 October, 2012.

Address of the President to the People of the Republic of Kazakhstan Strategy "Kazakhstan-2050" - new political course of the established state", December 15, 2012, available from:

http://www.akorda.kz/ru/page/page_poslanie-prezidenta-respubliki-kazakhstan-n-nazarbaeva-narodukazakhstana-14-dekabrya-2012-g_1355499089, accessed 14 October, 2013.

National Report on state and development of education, available from:

http://www.edu.gov.kz/fileadmin/user_upload/deyatelnost/nac_sistema_ocenki/Nacdoklad_2011_krat kaja_versija_na_russ.pdf, accessed 10 October, 2012.

State Program of Education Development of Kazakhstan for 2011-2020, available from: http://www.edu.gov.kz/ru/zakonodatelstvo/gosudarstvennaja_programma_razvitija_obrazovanija/, accessed 12 October, 2012. 